\title{
UP-SCALING FARMER FIELD SCHOOLS AND RAINFOREST ALLIANCE CERTIFICATION AMONG SMALLHOLDER TEA PRODUCERS IN KENYA: OPTIONS, OPPORTUNITIES AND EMERGING LESSONS

\author{
Stephen Wambugu Maina \\ Ministry of Agriculture - Narok South, Kenya \\ E-mail: Stephen67maina@yahoo.com
}

John Gowland-Mwangi

Egerton University, Egerton, Kenya

Email: mwangijg5@yahoo.com; mwangijg@gmail.com

Dave Boselie

The sustainability Initiative Utrecht, the Netherlands

Email: Boselie@idhsustainabletrade.com

Davies Onduru

Sustainable Agriculture and Rural Development

ETC East Africa Ltd, Kenya

Email: d.onduru@etc-eastafrica.org

Betty Chelang'at Buses

Ministry of Agriculture - Nakuru, Kenya

E-mail:bcbuses@yahoo.com

\begin{abstract}
The Kenya Tea Development Agency (KTDA) has been encouraging small-scale tea (Camellia sinensis) producers through Farmer Field Schools (FFS) to adopt good agricultural practices since 2006. The up-scaling of FFS and Rainforest Alliance (RA) certification to 560,000 tea producers remains a big challenge. Hence the need to learn about options, opportunities and emerging lessons for up-scaling FFS and RA certification among smallholder tea producers in Kenya. This study sought to improve tea stakeholders' understanding on how successful innovations such as FFSs and RA certification can be upscaled to more stakeholders and how to produce tea sustainably. It also sought to describe the options, opportunities and emerging lessons related to up-scaling. The study used a Cross-Sectional design to collect data from a two-stage random sample of 514 small-scale tea growers drawn from KTDA factories. A semi-structured questionnaire validated by extension experts, whose $0.92 \alpha$ reliability was above the 0.70 acceptable was used to collect data. Face-to-Face interviews, document analysis, record reviews, site visits, observations, living the system and a stakeholders' workshop were carried out to ensure triangulation. Data were analyzed using Chi-square at $0.05 \alpha$ set a priori. The results indicated that
\end{abstract}




\begin{abstract}
PROBLEMS
OF EDUCATION

IN THE $21^{\text {st }}$ CENTURY

Volume 43, 2012

142

certification. The researchers concluded that FFSs and RA certification can be up-scaled by increasing resources, improving communication, training and educating non-FFS members using different methods. They showed that up-scaling training for certification and FFS come with a need for additional investments and eventually will alter KTDA's cost and revenue model of the sustainable tea production. To sustain this system, the true costs and benefits of sustainable tea are incorporated in the KTDA business model, which implies that donors strategically move from subsidizing costs to strategic investments in human resource development, capacity building and extension technologies.
\end{abstract}

Key words: certification, emerging lessons, farmer field schools, good agricultural practices, Kenya Tea Development Agency, Rainforest Alliance, opportunities, options.

\title{
Introduction
}

Institutional failures, market constraints, limited education and knowledge transfer and adoption by farmers of improved technologies are largely responsible for reduced farm productivity and farmers' inability to generate income (Kilimo Trust, 2010) - leading to unnecessary poverty and food insecurity. Kenyan tea - world famous for its brightness, attractive color, brisk, flavor and texture (Mutai, 2011) face challenges of output and price fluctuations, inadequate affordable drought-tolerant clones and credit for buying essential farm inputs. According to Braga, Lonescu-Somer, and Seifert (2011), KTDA have been using Farmer Field Schools (FFS) since 2006 to training farmers, and to achieve sustainable tea production. By participating in the FFS, which is a learning-by-doing approach, farmers develop skills that enable them to identify and analyze their problems, opportunities, feasibility of different options, and to adapt to changing circumstances. This flexible, participant-led learning facilitates their demand for knowledge and enables them to choose, test and adapt useful technologies based on their needs (Mwangi, Oloo \& Maina, 2010). The FFS provides a forum for participant-led learning, flexible interactions and integration of different types of knowledge.

Tea is an important crop in East Africa, and is a source of income for countless smallholder farmers (Rainforest Alliance, 2011). The adoption of good agricultural practices (GAPS) in tea production through the conventional method of extension according to De Jager, Onduru, Hiller and Van den Bosch (2009) has proved to be slow and thus, FFS extension approach was adopted to increase the adoption of GAPS. Braga, Lonescu-Somer and Seifert (2011), Hiller, Onduru, and Jager (2009) have indicated that in 2006-2008, Kenya Tea Development Agency (KTDA) in cooperation with Lipton under the KTDA/Lipton Sustainable Agriculture Project launched four pilot FFSs spread equally over four KTDA factories under the Department for International Development (DFID) funding. They report that FFSs were used to successfully train smallholder tea producers on sustainable tea production practices, which constitute Good Agricultural Practices (GAPs); and the chain actors in the project expressed the need to roll-out the FFS approach to reach 560,000 tea producers using this methodology.

A number of quality assurance and certification initiatives such as Ethical Tea Partnership (ETP), Rainforest Alliance (RA), Fair Trade (FLO and IFAT) and Organic (IFOAM) have been started in the tea sector to guarantee quality to consumers and to take corporate social responsibility (De Jager et al., 2009). These initiatives, according to De Jager et al. (2009) have set standards and product labels assuring consumers that the products they purchase are produced, processed, and certified to be consistent with the set standards. During the pilot phase, Hiller et al. (2009) report that the need to attain Rainforest Alliance (RA) certification became apparent with LIPTON, the main buyer of KTDA tea, seeking to buy tea produced from sustainable sources. Rainforest Alliance promotes sustainable production through standards set by the Sustainable Agriculture Network (SAN) (Coffee \& Conservation, 2010, Rainforest Alliance, 2011). Rainforest Alliance (RA) certification - built on the three pillars of sustainability (environmental protection, social equity, and economic viability) - promotes and 
guarantees sustainable use of agricultural and forestry resources. The successful attainment of RA certification by the four factories according to The Standard (2011), in the pilot phase

PROBLEMS

OF EDUCATION

IN THE $21^{\text {st }}$ CENTURY

Volume 43, 2012 created interest in other KTDA factories to be RA certified, and since LIPTON wanted to buy tea from sustainable sources, a need arose to prepare other KTDA factories for RA certification (Van Tilburg et al., 2009). Hiller et al. (2009) have further indicated that in 2009, key partners (KTDA, RA, Unilever/Lipton, Wageningen University Research Centre-LEI, Africa Now (now Partner Africa), and ETC East Africa) initiated a second phase aimed at up-scaling FFS activities and RA certification work through the Scalability of Sustainable Tea Value Chain in Kenya. In 2009, Rainforest Alliance certification was granted to the first group of farmers, which according to Boselie, Hiller and Onduru (2010) allowed them to get better prices and market access in addition to higher yields and an improved environment.

\section{Problem of Research}

Despite the high demand, locally and internationally, for high quality tea that is safe to drink, some small-scale producers in Kenya have neglected and in extreme cases uprooted their tea bushes complaining of low prices and unprofitable returns. Failure to adopt good agricultural practices (GAPs) has led to low production of high value tea that can fetch higher and profitable returns. The adoption of GAPS in tea production through the conventional method of extension has proved to be slow and thus, FFS extension approach was adopted to explore its potentials in increasing the adoption of GAPS. In recent years, the Rainforest Alliance and other members of the Sustainable Agriculture Network (SAN) had little experience with tea. The up-scaling of SAN standards in Kenya remain a big challenge because of the large base of 560000 smallholder farmers organized around Kenya Tea Development Agency (KTDA) to be reached.

Furthermore, there is limited work done in documenting the experiences associated with RA certification and FFS as an extension approach among smallholder tea producers. Thus there is an emerging need to learn about options, opportunities and emerging lessons for up-scaling Farmer Field Schools and Rainforest Alliance certification among smallholder tea producers in Kenya.

\section{Research Focus}

Agriculture is key to Kenya's economy according to the Government of Kenya (2010), contributing $26 \%$ directly and another $25 \%$ indirectly of the GDP, accounting for $65 \%$ of Kenya's total exports and provides more than $18 \%$ of formal employment. Agricultural development, welfare of farmers and other people living in rural areas can be improved by providing agricultural extension and advisory services (Akinnagbe and Ajayi, 2010). The term extension was first used says Swanson and Rajalahti (2010), to describe adult education programs organized by Oxford and Cambridge universities in England in 1867 that helped extend the work of universities beyond the campus and into the neighboring communities. Akinnagbe and Ajayi (2010), Glendenning et al. (2010) and Swanson (2008), defined agricultural extension as the entire set of organizations that support and facilitate people engaged in agricultural production to solve problems and to obtain information, skills and technologies to improve their livelihoods and well-being. Agricultural education, extension, and advisory services says Davis et al. (2010) are a critical means of addressing rural poverty, through technology transfer, supporting learning, assisting farmers in problem solving, and enabling farmers to become more actively embedded in the agricultural knowledge and information system.

In 2008, Kenya and Sri Lanka produced approximately $65 \%$ of global black tea production (Braga, Lonescu-Somer \& Seifert, 2010). Tea is one of the most important agricultural crops in East Africa, and is a source of income for countless smallholder farmers (Rainforest Alliance, 
PROBLEMS

OF EDUCATION

IN THE $21^{\text {st }}$ CENTURY

Volume 43, 2012

144 tea (Breit, 2010, Gesimba, Langat, Liu, Wolukau, 2005, Obulutsa, 2010, Ombok, 2010) with approximately, 110,000 hectares of land under tea that is world famous for its brightness, attractive color, brisk, flavor and texture (Mutai, 2011). In 2009 the value of tea exports was Ksh 69 (US\$ 0.86) billion (Mugambi, 2010, Odhiambo, 2010). Kenya Tea Development Agency (KTDA) is the second largest exporter of black tea in the world and is responsible for $62 \%$ of all tea produced in Kenya (Braga, Lonescu-Somer, Seifert, 2011). To increase sustainable productivity, KTDA with its development partners has been using Farmer Field Schools (FFSs) since 2006 to enhance its smallholder tea producers' capacity in soft and technical skills (Odhiambo, 2010). The agro-ecological content and the experiential methodology of the FFS according to Stigter (2010) make it a popular training method to farmers.

Up-scaling or Scalability or Scaling-up refers to the diffusion and dissemination of locally successful innovations to a wider stakeholder group (Gordijn, 2005) and according to Sustainable Agriculture and Rural Development (2007), leads to "more quality benefits to more people over a wider geographic area more quickly, more equitably and more lastingly". With respect to the FFS, up-scaling requires mobilization of adequate human and material resources to replicate the model and also additional organization and finance to facilitate, channel and control the flow of information, goods and services efficiently and effectively (Davis, 2006). Campbell (2010) notes that FFS provides a scalable model for knowledge empowerment and can increase the potential scalability of sustainable technologies such as RA certification and any other program taught through FFS. Akinnagbe and Ajayi (2010) indicate that the Farmer Field School popularly known as "informal" or "school without walls" is a community-based, capacity building, learning by doing extension model or system that uses adult education principles in farmers' groups. This group-based experiential learning, Hartl (2009) and Mwangi, Oloo and Maina (2010) say, encourages farmers (normally in groups of 20-30) to learn improved technologies and farming practices through observation. Empowerment - an essential feature of the system according to Dzeco, Amilai and Cristóvão (2010) refers to the development of skills so that individuals can make informed choices in their lives. The FFS system was first introduced in Indonesia in 1989 to counter overuse of insecticides in irrigated rice fields during the Green Revolution (Campbell, 2010, Braun et al., 2006, Gallagher et al., 2006) and began in East Africa in 1995 (Davis et al., 2010).

A number of quality assurance and certification initiatives exist which apply or have been started in the tea sector to guarantee quality to consumers and to take corporate social responsibility (De Jager et al., 2009). They include UTZ Certified, Rainforest Alliance, ISO 9001:2008, ISO 14001:2004, ISO 26000, Ethical Tea Partnership (ETP), the International Organic Accreditation Service (IOAS) and Fair trade among others. Certification is a marketbased tool that provides the capacity to the customers to select the commodities based on their social and environmental concerns (Yadal, Kotwal, \& Menaria, 2007). The Rainforest Alliance is a non-profit organization (Hirt, 2011) that works with farmers and other agricultural producers to conserve biodiversity and promote sustainability. Ethical coffee (2011) defined the Rainforest Alliance as "a non-profit, tax-exempt organization based in New York with a mission to conserve biodiversity by promoting sustainability in agriculture, forestry, tourism and other businesses". Rainforest Alliance (RA) holds the Standards and Policy Secretariat for the Sustainable Agriculture Network and coordinates the development of standards and related policies for Sustainable Agriculture Network (Volkmann, 2008). To achieve RA certification strict health and safety principles such as working hours, rest periods, provision of safety equipment and sanitary facilities must be adhered to (Sustainable Agriculture Network, 2011). 


\section{Methodology of Research}

General Background of Research

A Cross-Sectional Survey Design, which is the scientific method for collecting and analyzing data gathered from two or more samples at one point in time (Mosby's Dental Dictionary, 2008) was used to collect both qualitative and quantitative data from smallholder tea producers. To help ensure an accurate and comprehensive investigation, Face-to-face interviews, document analysis, record reviews, site visits, observation, living the system and a stakeholders workshop were carried out. The study was undertaken in 25 KTDA factories located East and West of Kenya's Rift Valley, which divides the country right in the middle between East and West. Data was collected from KTDA factories in Embu, Meru, Kiambu, Murang'a, Kirinyaga and Nyeri counties in the East while those in the West are in Kericho, Bomet, Vihiga, Nandi, Mt Elgon, Nyamira and Kisii counties. These areas have tea as a major economic activity, most of the tea growers were small-scale farmers that delivered their tea to KTDA factories, Farmers Field School were being used as a training methodology, farmers had been trained in RA certification and the locations enabled to capture agro-ecological, ethnical, social-cultural diversity that characterized the tea growing areas in Kenya.

\section{Sample of Research}

The target population for this study was all KTDA smallholder tea producers totaling 560,000. A two-stage random sampling technique based on factories and Farmers Field School was used to sample 514 tea growers. A random sample of 25 KTDA factories was selected. A total of 20 FFSs members per factory were randomly selected purposively from FFS groups. A two-stage random sampling provided greater precision, guard against an unrepresentative sample and is less costly (Kothari, 2008). Data was collected from all FFS's' experts, and KTDA extension agents in the target area, from randomly selected representatives of FFS participants and tea stakeholders.

\section{Instrument and Procedures}

A questionnaire containing closed-ended and open-ended items and two check-lists developed by the researchers was used to collect qualitative and quantitative data from FFStrained tea growers, from RA trained farmers, FFS facilitators, farmers delivering tea to the 25 selected factories and from stakeholders in the value chain. Validity was ascertained by a panel of extension experts while a pilot test involving 30 farmers in Nandi County indicated the questionnaire's reliability coefficient of $0.92 \alpha$ which was above the threshold for acceptable reliability of $0.70 \alpha$, with the significance level set $a$ priori at $0.05 \alpha$.

\section{Data Analysis}

The data were expressed in charts, tables and an organization structure while Cross Tabulation and Chi-Square were used to determine association and relationships for categorical data. The quantitative data were coded and analyzed using the Statistical Package for Social Sciences (SPSS). Both qualitative and quantitative data were analyzed to inform the options, opportunities and provided emerging lessons for up-scaling FFS and RA certification. 
PROBLEMS

OF EDUCATION

IN THE $21^{\text {st }}$ CENTURY

Volume 43,2012

146

\section{Results of Research}

To enhance up-scaling of FFSs and RA Certification (Table 1), over 23\% of the FFS members suggested to be facilitated to visit other successful groups, $21 \%$ suggested empowering FFS trained farmers to form, facilitate and train new FFS, 19\% Support FFS groups with material resources and 16\% suggested providing funds to paying farmer led-FFS facilitators and FFS members. Approximately $16 \%$ of the respondents suggested facilitation of members in FFS to become role models by motivating them, $12 \%$ suggested KTDA to increase the number of farmer-led FFS and RA facilitators, 6\% suggested popularizing FFS and RA certification through public forums like barazas, $5 \%$ to reduce the costs involved in RA certification while 5\% suggested Reduced FFS meeting time.

\section{Table 1. Suggestions by Farmers on How to Up-scale FFSs or RA Certification} $(\mathrm{N}=514)$.

\begin{tabular}{|c|c|c|}
\hline Suggestions by farmers on how to up-scale FFSs or RA Certification & Frequency & $\%$ \\
\hline FFS members to be facilitated to visit other successful groups & 121 & 23.5 \\
\hline Empower FFS trained farmers to form, facilitate and train new FFS & 108 & 21.0 \\
\hline Support FFS groups with material resources & 100 & 19.5 \\
\hline Provide funds to paying farmer led-FFS facilitators and FFS members & 81 & 15.8 \\
\hline Facilitate members in FFS to become role models by motivating them & 80 & 15.6 \\
\hline KTDA to increase the number of farmer-led FFS and RA facilitators & 63 & 12.3 \\
\hline Popularize FFS and RA certification through public forums like barazas & 32 & 6.2 \\
\hline Reduce the costs involved in RA certification & 28 & 5.4 \\
\hline Reduce FFS meeting time & 24 & 4.7 \\
\hline Use the tea buying centre as avenues for training FFS by Lead farmers & 16 & 3.1 \\
\hline $\begin{array}{l}\text { Improving linkages of FFS members to other extension providers, FFS networks and initiate } \\
\text { income generating projects }\end{array}$ & 11 & 2.1 \\
\hline Increase the number of FFS facilitators & 9 & 1.8 \\
\hline Reward farmers that have implemented RA in their farm & 6 & 1.2 \\
\hline
\end{tabular}

Half (50\%) of the FFS members (Figure 1) said they were taught through a combination of English, Kiswahili and Vernacular, 23\% of them communicated using vernacular alone, $21 \%$ Kiswahili and Vernacular and 6\% in English and Vernacular. Over 94\% of smallholders indicated the language used in their FFS was appropriate. 


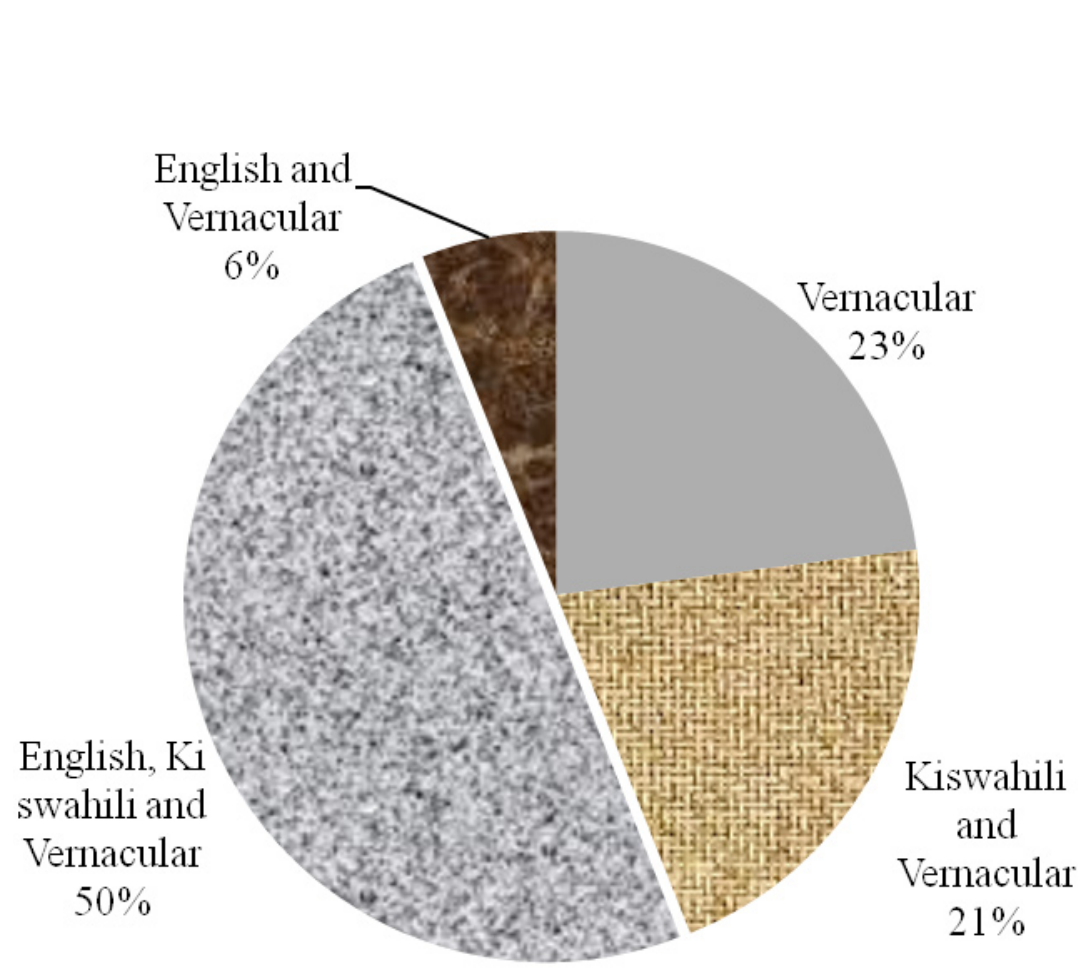

Figure 1: Main language used in the FFS and RA training.

Over $53 \%$ of the FFS members grew tea in their individual farms, $43 \%$ of them grew at the family land and $4 \%$ grew on hired land (Table 2). Less than a third $(30 \%)$ of the FFS groups had income generating activities. About $10 \%$ of the income generating projects were in horticulture and bee keeping, $8 \%$ in table-banking and 3\% in tea nursery and seedlings. Over $14 \%$ of the proceeds from income generating activities in FFS were used to buy farm inputs, $10 \%$ to save in a cooperative society, $9 \%$ to buy food, $8 \%$ to buy tea seedlings for gaping and $6 \%$ to hire farm labour. Over $90 \%$ of the tea based FFS were facilitated by KTDA extension agent with 77\% FFS members rating of the FFS facilitator's expertise in guiding the FFS activities as high.

About $84 \%$ of the FFS members indicated that farmers' adapting available technology effectively for tea improvement was one of the factors that explained how tea-related FFS upscaling processes work. Approximately $69 \%$ of the FFS members indicated that FFS up-scaling process can be improved by reducing success-related challenges through proactive strategic research, $70 \%$ indicated FFS up-scaling process can be improved by engaging in strategic partnerships with relevant stakeholders, $61 \%$ indicated it can be improved by developing new markets that are responsive to consumer tastes, $76 \%$ indicated improvement through networking with stakeholders who are involved in FFS up-scaling while $80 \%$ indicated careful monitoring and assessment of impacts as another factor that explained how tea-related FFS up-scaling processes work. 
PROBLEMS

OF EDUCATION

IN THE $21^{\text {st }}$ CENTURY Volume 43, 2012

148

Table 2. Factors that explain how up-scaling processes work $(\mathbf{N}=\mathbf{5 1 4})$.

\begin{tabular}{|c|c|c|}
\hline Factors & Frequency & Percent \\
\hline \multicolumn{3}{|c|}{ The type of land tenure system among tea growers } \\
\hline Individual land tenure system & 272 & 53.0 \\
\hline Family land & 221 & 43.0 \\
\hline Hired land & 21 & 4.0 \\
\hline FFS groups with income-generating activities & 154 & 30.0 \\
\hline \multicolumn{3}{|l|}{ Income generating activities by the FFS groups } \\
\hline Horticulture and bee keeping & 49 & 9.5 \\
\hline Table banking/Merry go round & 39 & 7.6 \\
\hline Tea nursery and selling tea seedlings & 16 & 3.1 \\
\hline Soap making & 7 & 1.4 \\
\hline Agro-forestry tree nurseries & 4 & .8 \\
\hline Pruning machine & 1 & .2 \\
\hline Keeping goat & 1 & .2 \\
\hline \multicolumn{3}{|c|}{ How FFS group members used the proceeds from income generating activities } \\
\hline Buying farm inputs & 74 & 14.4 \\
\hline Saving in a SACCO & 53 & 10.3 \\
\hline Buying food & 46 & 8.9 \\
\hline Buying seedlings for gaping (infilling) & 43 & 8.4 \\
\hline Hiring farm labour & 31 & 6.0 \\
\hline Training materials & 22 & 4.3 \\
\hline Paying facilitators & 3 & 6 \\
\hline \multicolumn{3}{|l|}{ Who Facilitates the tea based FFS } \\
\hline KTDA extension agent. & 466 & 90.7 \\
\hline FFS-trained farmer & 46 & 8.9 \\
\hline None-farmer expert & 2 & .4 \\
\hline \multicolumn{3}{|c|}{ FFS members rating of the facilitator's expertise in guiding the FFS activities } \\
\hline High & 396 & 77.0 \\
\hline Moderate & 117 & 22.8 \\
\hline Low & 1 & .2 \\
\hline FFS group member, have you been involved in collective tea marketing & 23 & 4.5 \\
\hline \multicolumn{3}{|l|}{ Factors explaining how tea-related FFS up-scaling processes work } \\
\hline Farmers adapting available technology effectively for tea improvement. & 433 & 84.2 \\
\hline Reducing success-related challenges through proactive strategic research & 352 & 68.5 \\
\hline Engaging in strategic partnerships with relevant stakeholders. & 359 & 69.8 \\
\hline Developing new markets that are responsive to consumer tastes. & 315 & 61.3 \\
\hline Improving networking with stakeholders involved in FFS up-scaling. & 392 & 76.3 \\
\hline Careful monitoring and assessment of impacts. & 412 & 80.2 \\
\hline
\end{tabular}


Stephen WAMBUGU MAINA, John GOWLAND-MWANGI, Dave BOSELIE, Davies ONDURU, Betty CHELANG'AT BUSES. Up-Scaling Farmer Field Schools and Rainforest Alliance Certification among Smallholder Tea Producers in Kenya: Options, Opportunities and Emerging Lessons

Over $93 \%$ of the FFS members interviewed (Table 3) indicated that their FFS had an established leadership structure which included the position of chairman, secretary, treasurer and committee members. Smallholder farmers in the FFS exercised various leadership roles as group officials, members, time keepers, lead farmers, appreciating visitors and group members through clapping, singer, energizer and FFS pastors. About 37\% of the FFS groups were linked to other networks, groups or partners. About $12 \%$ of them were linked to the Ministry of Agriculture, Ministry of Livestock or Dairy Goat Association of Kenya that provided extension and training. Over 4\% were linked to other FFS groups while 3\% were linked to farmers' forums. Over $20 \%$ of the FFS members benefited through exchange of ideas, skill and experience from the linkages or networks, $5 \%$ of the FFS groups got trainers and facilitators to their FFS group, $4 \%$ enjoyed community relations, $2 \%$ were provided with credits and markets or benefited from acquisition of inputs to the FFS members.

Table 3. Governance in FFS $(\mathrm{N}=514)$.

\begin{tabular}{|c|c|c|}
\hline Leadership structure in your FFS & Frequency & Percent \\
\hline FFS groups with an established leadership structure & 496 & 96.5 \\
\hline Chairman & 495 & 96.3 \\
\hline Secretary & 494 & 96.1 \\
\hline Treasurer & 476 & 92.6 \\
\hline Committee member & 490 & 95.3 \\
\hline \multicolumn{3}{|c|}{ Leadership roles (duties) in the FFS } \\
\hline FFS Member & 198 & 38.5 \\
\hline Chairman, chairlady of the sub group, vice-chairman & 72 & 14.0 \\
\hline Host and in-charge of plucking tea at the experiment plots in the farm & 8 & 1.6 \\
\hline Secretary, vice secretary, sub group secretary, & 119 & 23.2 \\
\hline Treasurer & 11 & 2.1 \\
\hline Appreciating visitors and group members by clapping and singing & 12 & 2.4 \\
\hline Trainer/Lead farmer/ Facilitator & 13 & 2.5 \\
\hline Lead prayers in FFS meetings, pastor & 8 & 1.6 \\
\hline Provide and preparing venue for FFS meetings & 2 & .4 \\
\hline Time keeper and discipline master & 21 & 4.1 \\
\hline FFS groups linked to other networks, groups or partners & 190 & 37.0 \\
\hline \multicolumn{3}{|c|}{ Name of the FFS networks groups or partners the FFS groups are linked to } \\
\hline Government Ministries or Dairy Goat Association of Kenya & 61 & 11.9 \\
\hline FFS groups/Networks & 18 & 3.5 \\
\hline Mununga integrated forum & 13 & 2.5 \\
\hline UTZ Certification & 5 & 1.0 \\
\hline Other groups in table banking & 1 & .4 \\
\hline Buyers of tree seedlings & 1 & .4 \\
\hline Muramati Sacco/bank & 2 & .4 \\
\hline Mwanga & 1 & .2 \\
\hline Coffee farmers & 1 & .2 \\
\hline Iruma & 1 & .2 \\
\hline \multicolumn{3}{|c|}{ Various ways that FFS groups benefit from the linkages or networks } \\
\hline Exchange of ideas, skill and experience & 102 & 19.8 \\
\hline Benefited from trainers, and facilitators to the FFS group & 25 & 4.9 \\
\hline Community relations & 21 & 4.1 \\
\hline Credits and marketing together & 9 & 1.8 \\
\hline Provided and facilitated acquisition of inputs to the FFS members & 8 & 1.6 \\
\hline
\end{tabular}


PROBLEMS

OF EDUCATION

IN THE $21^{\text {st }}$ CENTURY

Volume 43,2012

The main information source (Figure 2) on Farmer Field Schools and Rainforest Alliance certification was extension officers $(85 \%$ and $78 \%$ ), followed by Kenya Tea Development Agency (71\% and 70\%), Farmer Field Schools (39\% and 47\%), farmer-teachers (24\% and $25 \%)$ and farmer groups (22\% and $21 \%)$ respectively. Newspaper and churches were other important sources of information for FFS and RA certification.

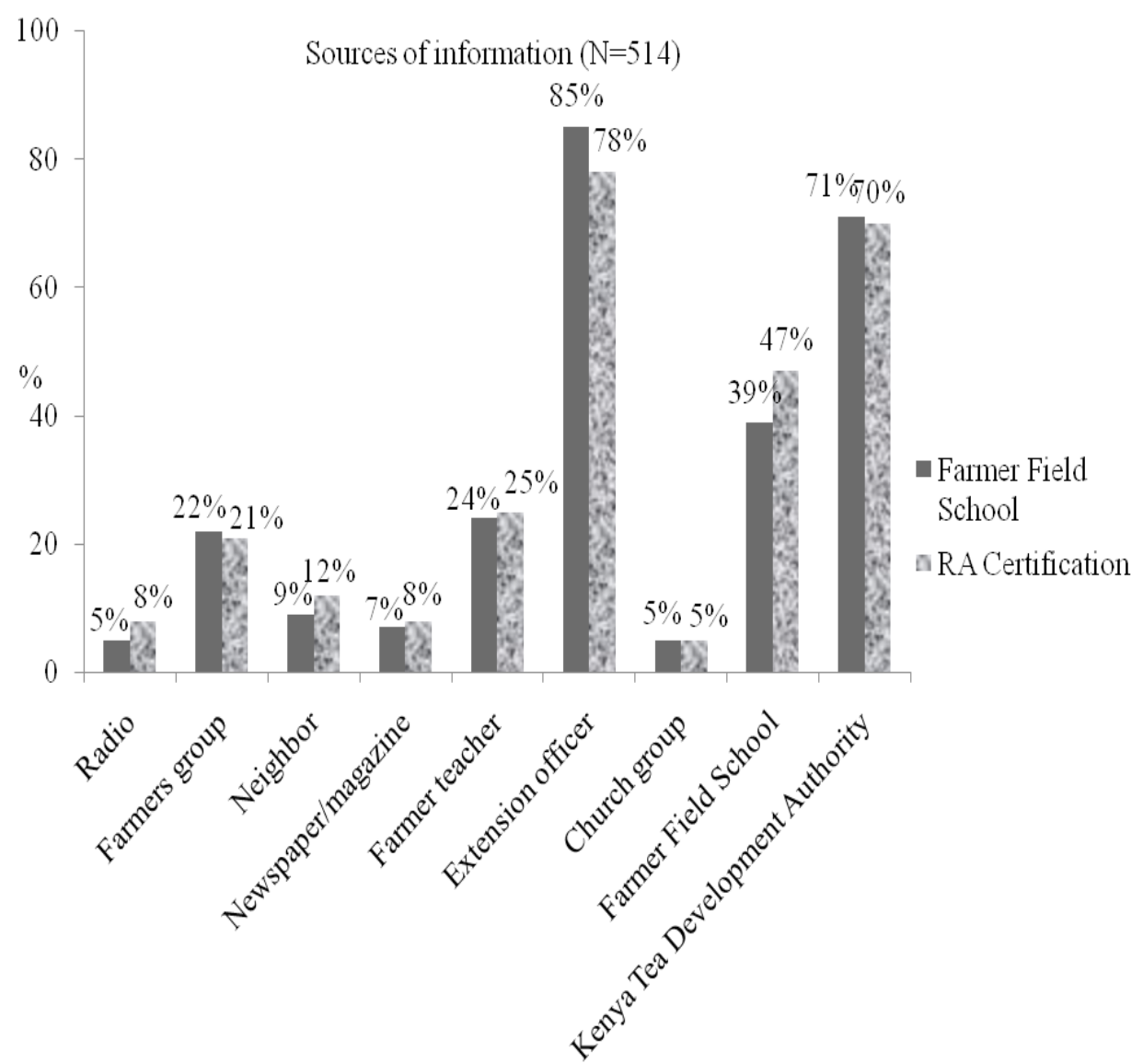

Figure 2: First sources of information on FFS and RA certification.

The results (Table 4) indicated four options for up-scaling Farmer Field Schools and Rainforest Alliance certification. They include:

1. Maintain the system as it is. The strength of this option is that it is already working, many FFSs are operational and some factories are RA compliant. The major weakness is that it may take longer before all KTDA farmers are reached and the speed of scalability will be slowed or halted.

2. Have FFS only: The strength of this option is that farmers will benefit from hands on experience. However, farmers will miss benefits of RA certification and this methodology may not reach educated and well to do farmers, whose opportunity cost of attending FFSs is very high.

3. Have RA only: The strength of this option is that all physical and human resources can be used to enhance RA certification. But RA certification deals with tea that is already established and therefore prospective tea growers will not benefit from RA certification in the initial stage of developing their tea farms. Also, farmer might not benefit from other extension methods such as field days and other methods of transferring technologies. 

Farmer Field Schools and Rainforest Alliance Certification among Smallholder Tea Producers in Kenya: Options, Opportunities and Emerging Lessons

4. Maintain the current system with some improvements including use of field days, farm visits and mass media. The strength of this option is that compliance with up-scaling of FFS and RA certification would be faster and would benefit more farmers, the quantity and quality of sustainable tea would be increased, market accessibility would be guaranteed and all stakeholders in the value chain would benefit from sustainable tea. More physical and human resource would be required. However, goodwill from different stakeholders will be required to make the system efficient and effective. Improvement on this option can be made to reach educated and well-to do farmers through information technology like Internet and Telephone messaging, Initiate farmer-led FFS, Involve other stakeholders and Ensure that in the management structure of KTDA people are specifically assigned to do participatory monitoring and evaluation.

Table 4. Options for up-scaling Farmer Field Schools and Rainforest Alliance Certification.

\begin{tabular}{|c|c|c|c|}
\hline Option & Strengths & Weaknesses & $\begin{array}{c}\text { Proposal for improvements/ } \\
\text { implications }\end{array}$ \\
\hline $\begin{array}{l}\text { Maintain the } \\
\text { system as it is }\end{array}$ & $\begin{array}{l}\text { It is already working. } \\
\text { Many FFSs are } \\
\text { operational and some } \\
\text { factories are RA compli- } \\
\text { ant }\end{array}$ & $\begin{array}{l}\text { It may take longer before all } \\
\text { KTDA farmers are reached }\end{array}$ & $\begin{array}{l}\text { Implication } \\
\text { A. People are satisfied with its } \\
\text { current performance } \\
\text { B. No additional investment of } \\
\text { staff and resources } \\
\text { C. Speed of scalability will be } \\
\text { slowed or halted }\end{array}$ \\
\hline Have FFS only & $\begin{array}{l}\text { Farmers will benefit } \\
\text { from hands on experi- } \\
\text { ence }\end{array}$ & $\begin{array}{l}\text { Farmers will miss benefits of RA } \\
\text { certification. } \\
\text { FFSs may not reach educated } \\
\text { and well to do farmers, whose } \\
\text { opportunity cost of attending } \\
\text { FFSs is very high }\end{array}$ & $\begin{array}{l}\text { Implication } \\
\text { Farmer might not benefit from } \\
\text { other extension methods such as } \\
\text { field days and other methods of } \\
\text { transferring technologies }\end{array}$ \\
\hline Have RA only & $\begin{array}{l}\text { All physical and human } \\
\text { resources can be used } \\
\text { to enhance RA certifica- } \\
\text { tion }\end{array}$ & $\begin{array}{l}\text { RA certification deals with tea } \\
\text { that is already established } \\
\text { and therefore prospective tea } \\
\text { growers will not benefit from RA } \\
\text { certification in the initial stage of } \\
\text { developing their tea farms. }\end{array}$ & $\begin{array}{l}\text { Implication } \\
\text { Farmer might not benefit from } \\
\text { other extension methods such as } \\
\text { field days and other methods of } \\
\text { transferring technologies. }\end{array}$ \\
\hline $\begin{array}{l}\text { Maintain the } \\
\text { current system } \\
\text { with improve- } \\
\text { ments that in- } \\
\text { clude field days, } \\
\text { farm visits and } \\
\text { mass media. } \\
\text { This scenario is } \\
\text { a combination } \\
\text { of the FFS and } \\
\text { Training for RA } \\
\text { certification }\end{array}$ & $\begin{array}{l}\text { Compliance with up- } \\
\text { scaling of FFS and RA } \\
\text { certification would be } \\
\text { faster and would benefit } \\
\text { more farmers. } \\
\text { The quantity and qual- } \\
\text { ity of sustainable tea } \\
\text { would be increased. } \\
\text { Market accessibility } \\
\text { would be guaranteed. } \\
\text { All stakeholders in } \\
\text { the value chain would } \\
\text { benefit from sustainable } \\
\text { tea production }\end{array}$ & $\begin{array}{l}\text { More physical and human } \\
\text { resource would be required. } \\
\text { Goodwill from different stake- } \\
\text { holders will be required to make } \\
\text { the system efficient and effective }\end{array}$ & $\begin{array}{l}\text { Reach educated and well-to } \\
\text { do farmers through information } \\
\text { technology like Internet and } \\
\text { Telephone messaging. } \\
\text { Initiate farmer-led FFS } \\
\text { Involve other stakeholders. } \\
\text { Ensure that in the management } \\
\text { structure of KTDA people are } \\
\text { specifically assigned to do PM\&E }\end{array}$ \\
\hline
\end{tabular}

PROBLEMS

OF EDUCATION

IN THE $21^{\text {st }}$ CENTURY

Volume 43, 2012 
PROBLEMS

OF EDUCATION

IN THE $21^{\text {st }}$ CENTURY

Volume 43,2012

152

The research results have indicated various opportunities for up-scaling Farmer Field Schools and Rainforest Alliance certification among smallholder tea producers. They include (1) Many stakeholders are aware and would probably support harmonization of various certification standards in the tea sector because it would remove duplication and ineffective use of physical and human resources thereby reducing costs of compliance; (2) Most smallholder farmers own land and can decide on how it is used for up-scaling FFS and RA certification; (3) There is goodwill from stakeholders to support scalability of FFS and RA certification; (4) Learning from stakeholders on how to manage time so that farmers are not bored or loose interest during FFS sessions; (5) Improve FFS and facilitators' efficiency and effectiveness in sustainable tea production by increasing resources for buying PPEs, tree seeds and seedlings and for the collection and disposal of non-biodegradable and recyclable materials; (6) Building the capacity of lead farmers to deliver extension services more effectively; (7) Improve communication and training of staff and farmers to enhance adoption of FFS and RA certification principles; (8) Educating non-FFS members on the benefits of FFS and RA principles; and (9) Using a variety of methods to disseminate information on FFS and RA certification.

The results showed emerging lessons for up-scaling Farmer Field Schools and Rainforest Alliance certification among smallholder tea producers in Kenya. They include (1) Most stakeholders do not fully understand the concept and value of cost-sharing in the scalability process of FFS and RA certification. (2) An understanding of the value and usefulness of FFS and RA certification would motivate stakeholders to morally and financially support the scalability process. This lesson is very important because the business case for certification and FFS has not been clear to any of the stakeholders. The actual costs and benefits for conversion, compliance and mainstreaming of sustainability in all factories has not yet systematically been analyzed and shared transparently with all stakeholders. (3) Graduates of FFS can be effectively used to enhance scalability of FFS and RA certification because they know the area well, are cheaper, are readily available and are willing to do the job at a lower cost. (4) Proper and timely training of staff and farmers on the scalability of FFS and RA certification can enhance its implementation. (5) During the time reserved for preparing factories for RA certification, the staffs involved tend to focus too much time on that activity at the expense of other equally important issues. (6) In addition to KTDA, other actors are required to harness the tea growers' diverse socio-economic status, needs and priorities. (7) Most of the tea factories that had received RA certification had benefited from financial sponsorship by would-be buyers or Sustainable Trade Initiative (IDH). (8) Some tea producers have not yet fully owned the RA certification practices as part of sustainable tea production. (9) Although barazas, tea buying centres and other farmers' forums can be used for sensitizing RA certification, they would be more effective if supported by intensive training and demonstrations. (10) Recruiting lead farmers without some minimum qualification requirements made them unable to train their fellow tea growers effectively. (11) Governance and conflict resolution can be improved by providing a feedback mechanism in which FFS members freely express their concerns and recommendations. (12)There is insufficient effort to target youthful, elderly and women tea producers. (13) FFSs with a variety of income-generating activities such as agro-forestry, tree nursery, bee keeping, rabbit keeping, horticulture and harvesting of water run-off are likely to be more sustainable. The income generated from such ventures can partially and to some extent fully used to hire facilitators, paying variable costs and providing success stories. (14) Recruiting FFS members through barazas by asking for volunteers affects group cohesion, learning and sustainability. (15) FFSs' total dependence on KTDA factories for financial support affects their sustainability but linking them to other stakeholders such as NGOs and Government ministries improves sustainability. (16) Increased up-scaling poses a challenge in building FFS group cohesion and information-sharing among the stakeholders such as the KTDA head office, KTDA factories and FFS networks. (17) Some farmers have inadequate understanding of the benefits of RA 
certification. (18) Tea growers do not understand why they are not paid for attending KTDAorganized activities while other organizations pay them for attending their meetings. (19) In

PROBLEMS

OF EDUCATION

IN THE $21^{\text {st }}$ CENTURY

Volume 43, 2012

some areas, farmers were willing to attend FFS meetings but because they depended on meager daily pay for their subsistence, they often opted to go for activities that earned them money.

\section{Discussion}

The research findings agree with those of Eicher (2007) that the success of a Farmer Field School depends largely on the motivation and dedication of its participants. The suggestion to increase the number of farmer-led FFS and RA facilitators by employing/engaging FFS graduates permanently to train other farmers agrees with Bunyatta et al. (2006) and Rusike et al. (2004) that most FFS's graduates are willing to share information with other farmers and to facilitate the formation of more FFS in their communities if given financial support. Stigter (2010) proposed a strategy of up-scaling using farmer-led and partial self-funded FFSs. The findings revealed that the presence of secure land tenure systems supported the FFS and RA certification scaling-up efforts which agree with the finding of the Sustainable Agriculture and Rural Development (2007). Less than a third (30\%) of the FFS groups had income generating activities yet income generating activities increase sustainability and effectiveness of the overall FFS approach because the proceeds to buy farm inputs, save in a cooperative society, buy food, buy tea seedlings for gaping and even hire farm labour. Over $90 \%$ of the tea based FFS were facilitated by KTDA extension agent with $77 \%$ FFS members rating of the FFS facilitator's expertise in guiding the FFS activities as high. This agrees with Hartl (2009) and Endalew (2009) assertion that the FFS facilitators must have skills to addressing farmers' need, managing participatory, discovery-based learning as well as technical knowledge to guide the groups' learning and action process, and help in reducing dependence of FFS groups on external support, besides up-scaling FFS coverage, increasing sustainability and effectiveness of the overall FFS approach.

The findings revealed that upscaling of FFS could be enhanced by farmers' adapting available technology effectively for tea improvement, reducing success-related challenges through proactive strategic research, engaging in strategic partnerships with relevant stakeholders, developing new markets that are responsive to consumer tastes, networking with stakeholders who are involved in FFS up-scaling and careful monitoring and assessment of impacts. The findings showed that Over $93 \%$ of the FFS members an established leadership structure, that smallholder farmers in the FFS exercised various leadership roles, and only a third of the FFS groups were linked to other networks, groups or partners. Linkages to networks federations/ associations according to Braun et al. (2006), Nyambati et al. (2011) and World Economic Forum (2011) connect FFS members by bringing them close to government institutions and other service providers such as micro-credit institutions, research and development organizations and thus improving the efficiency effectiveness and sustainability of the up-scaling process. FFS members also gain self-confidence, get empowered, exercise leadership and play an important role for strengthening rural institutions (Hartl, 2009) and assist FFS groups to be self-evolving, grow strong, cultivate mutual trust, transparency, good and democratic leadership (Food and Agriculture Organization, 2008).

The findings revealed that there is an oportunity to up-scale FFS and RA certification by using other methods of training farmers and creating awareness such as Newspaper, radio, television, churches among others. The findings indicated four options for up-scaling Farmer Field Schools and Rainforest Alliance certification namely mmaintaining the system as it is, have FFS only, have RA only or maintaining the current system with some improvements including use of field days, farm visits and mass media. Maintaining the current system with some improvements is the best option because the compliance with up-scaling of FFS and 
PROBLEMS

OF EDUCATION

IN THE $21^{\text {st }}$ CENTURY

Volume 43, 2012

154

RA certification would be faster and would benefit more farmers, the quantity and quality of sustainable tea would be increased, market accessibility would be guaranteed and all stakeholders in the value chain would benefit from sustainable tea. More physical and human resource would be required. However, goodwill from different stakeholders will be required to make the system efficient and effective.

The research findings also indicated various opportunities for up-scaling Farmer Field Schools and Rainforest Alliance certification among smallholder tea producers which can be utilized such as improving FFS and facilitators' efficiency and effectiveness in sustainable tea production by increasing resources for buying PPEs, tree seeds and seedlings and for the collection and disposal of non-biodegradable and recyclable materials, building the capacity of lead farmers to deliver extension services more effectively, improving communication and training of staff and farmers to enhance adoption of FFS and RA certification principles, Educating non-FFS members on the benefits of FFS and RA principles, and using a variety of methods to disseminate information on FFS and RA certification. The results showed emerging lessons for up-scaling Farmer Field Schools and Rainforest Alliance certification among smallholder tea producers in Kenya. An understanding of the value and usefulness of FFS and RA certification would motivate stakeholders to morally and financially support the scalability process. Graduates of FFS can be effectively used to enhance scalability of FFS and RA certification because they know the area well, are cheaper, are readily available and are willing to do the job at a lower cost. Proper and timely training of staff and farmers on the scalability of FFS and RA certification can enhance its implementation. Recruiting lead farmers without some minimum qualification requirements made them unable to train their fellow tea growers effectively. FFSs with a variety of income-generating activities such as agro-forestry, tree nursery, bee keeping, rabbit keeping, horticulture and harvesting of water run-off are likely to be more sustainable and are likely to afford hiring facilitators, paying variable costs and providing success stories. In some areas, farmers were willing to attend FFS meetings but because they depended on meager daily pay for their subsistence, they often opted to go for activities that earned them money.

All the issues discussed in this study are intertwined. While improvements in the system are envisaged in the short and in the long term, a general consensus has emerged for: (i) Using selected FFS graduates as Lead Farmers in RA Certification training and farm inspections to tap into the two knowledge bases provided through FFS and RA Certification training (ii) integrating some of the Good Agricultural Practices in the SAN Standard in FFS sessions such as safe use of agrochemicals and riverine protection; and (iii) using field days and tea buyingcentre meetings to sensitize farmers on both RA and FFS issues. Managing these changes require institutional and policy adjustments within KTDA and enhanced dialogue with existing donors and collaborators for strategic intervention that can ensure continuity beyond donor funding. Since development is an on-going continuum, the challenge is that most projects/ programs have short life cycles and are rarely implemented within a time frame and a funding cycle that allows for the process of change to fully take place unless strategic interventions on sustainability are in-built. This probably, explains why IDH may be exploring the option of strategic resource development that would make the system self-sustaining. Most of the project costs in phase 1 were largely met by the donors. During the next phase it will be advisable to create structures and process within KTDA that can sustain the system of certification. KTDA is now bearing the costs of audit fees and lead farmers previously borne by RA/ IDH funding, but more costs such as those for RA trainings are still being met by donors. While this line of thinking holds, arguments exist that when KTDA in-kind contribution (human resources and staff time) is fully documented/ "monetarized" as opportunity cost, then the current perceptions on cost structure on RA certification may probably look different. With regards to marketing, there is still room for improvement. Fortunately, KTDA has started an initiative to make every 
buyer of RA certified tea to pay "sustainability fees" which will eventually ploughed back to the factories to partially cater for the costs of certification though the initiative is still at its infancy stage.

\section{Conclusions}

Based on the results of the study, the researchers concluded that up-scaling of FFS and RA certification can be enhance; farmers can adapt available tea production technologies effectively; success-related challenges can be reduced through proactive strategic research and through engaging in strategic partnerships with relevant stakeholders; new markets that are responsive to consumer tastes can be developed and networks with stakeholders who are involved in FFS up-scaling and careful monitoring and assessment of impacts can be created. Many FFS groups had an established leadership structure and smallholder farmers in the FFS exercised various leadership roles. Only a third of the FFS groups were linked to other networks, groups or partners. The study concluded that there is an oportunity to up-scale FFS and RA certification by using other methods of training farmers. The study also concluded that among the options for up-scaling FFS and RA certification, maintaining the current system with some improvements is the best option. The study concluded that there are opportunities for upscaling FFSs and RA certification by increasing resources to FFS and facilitators; improving communication and training of staff and farmers; educating non-FFS members on the benefits of FFS and RA principles; and using a variety of methods to disseminate information on FFS and RA certification. Based on the findings in this study, the role of the main donors, namely IDH and the Netherlands Embassy should change from what it was during the first phase in order to meet the identified requirements for up-scaling. While in phase 1 the donors basically subsidized certain costs of training, audits and certification, during the next phase they should invest strategically in specific resources. They can do this by funding activities for increasing the number of farmer-led FFS and RA facilitators; developing new markets that are responsive to consumer tastes; improving communication and training of staff and farmers; educating non-FFS members on the benefits of FFS and RA principles; and using different methods to disseminate FFS and RA certification information. The study concluded that there are emerging lessons for up-scaling FFSs and RA certification. These include an understanding of the value and usefulness of FFS and RA certification, improved sustainability via FFS training and RA certification that comes with a new cost structure for KTDA as a whole. The true cost of sustainable tea has to be rewarded by the market and the end consumer. This sustainability premium requires a marketing/ branding effort by KTDA. It should not depend on continuous subsidies by donors.

\section{Acknowledgements}

We would like to pass our sincere gratitude to staff at ETC-East Africa and the Embassy of the Kingdom of the Netherlands in Kenya for awarding us the research funds and to fellow colleagues at the Department of Agricultural Education and Extension, the Dean of the Faculty of Education and Community Studies; and the Director of Graduate School of Egerton University for ascertaining the questionnaire's content validity, and to all smallholder tea farmers and all KTDA field extension officers involved in the study for their support. 
PROBLEMS

OF EDUCATION

IN THE $21^{\text {st }}$ CENTURY

Volume 43, 2012

156

\section{References}

Akinnagbe, O. M., \& Ajayi, A. R. (2010). Challenges of farmer-led extension approaches in Nigeria. World Journal of Agricultural Sciences, 6 (4), 353-359.

Boselie, D., Hiller, S., \& Onduru, D. (2010). Enhancing learning within certification schemes. Farming Matters vol. 26-Proof/Improve, Working-and-learning together. Partnerships for learning.

Braga, T., Lonescu-Somer, A., \& Seifert, R. (2011). Case study Unilever sustainable tea Part II: Reaching out to small holders in Kenya and Argentina. Dutch Sustainable Trade Initiative.

Braga, T., Lonescu-Somer, A., \& Seifert, R. (2010). Case Study. Unilever sustainable tea. Part 1: Leapfrogging to mainstream. Dutch Sustainable Trade Initiative.

Braun, A., Jiggins, J., Roling, N., van den Berg, H., \& Snijders, P. (2006). A global survey and review of farmer field school experiences. Report prepared for the International Livestock Research Institute (ILRI).

Breit (2010). The Kenyan tea industry, the top tea exporter in the world, produced 246.3 million pounds of tea, marking a five-year high for Kenya. Tea exports rose by $24 \%$ from the 2009 level.

Bunyatta, D. K., Mureithi, J. G., Onyango, C. A., \& Ngesa, F. U. (2006). Farmer field schools effectiveness for soil and crop management technologies in Kenya, Njoro, Kenya. Retrieved on $13^{\text {th }}$ December 2010 from http://www.aiaee.org/attachments/159_Vol-13.3.pdf.

Campbell, C. (2010). Agricultural Man Ecology Foundation (AME): Farmer Field School. Development Dialogue 2010.

Coffee and Conservation (2010). Rainforest Alliance Cupping for Quality.

Davis, K. (2006). Farmer Field School: A boon or bust for extension in Africa. Journal of International Agricultural and Extension Education, 13 (1), 1-10.

Davis, K., Nkonya, E., Mekonnen, D. A., Odedo, M., Miiro, R., \& Nkuba, J. (2010). Impact of FFS on agricultural productivity and poverty in East Africa. IFPRI Discussion Paper 00992 June 2010.

De Jager, A., Onduru, D. D., Hiller, S., \& Van den Bosch, R. (2009). Sustainability of smallholder tea production in developing countries: Experiences from Kenya.

Dzeco, C., Amilai, C., \& Cristóvão, A. (2010). Farm field schools and farmer's empowerment in Mozambique: A pilot study. 9th European IFSA Symposium, $4 \square 7$ July 2010, Vienna (Austria).

Eicher, C. K. (2007). Agricultural Extension in Africa and Asia. Retrieved on $3^{\text {rd }}$ January 2011 from http:// www.wordaginfo.org/drupal/files/Agriculture ExtensioninAfricaandAsia2.pdf.

Endalew, B. D. (2009). Effectiveness of farmer field school in promoting coffee management practices: The case of Jimma and Sidama zones. Msc. thesis. Haramaya University.

Ethical coffee (2011). Rainforest Alliance certification. Retrieved from http://www.ethicalcoffee.net/ rainforest.html

Food and Agriculture Organization (FAO). (2008). Farmer field schools on land and water management in Africa: Proceedings of an international workshop in Jinja, Uganda on 24-29 April 2006.

Gallagher, D. K, Braun, R. A., \& Duveskog, D. (2006). Demystifying Farmer Field School Concept: Retrieved $2^{\text {nd }} 2011$ January from http://www.share4dev.info/ffsnet/documents/3200.pdf.

Gesimba, R. M., Langat, M. C., Liu, G., \& Wolukau, J. N. (2005). The challenges and positive developments of the tea industry in Kenya. Journal of Applied Science, 5 (2), 334-336. Retrieved on $13^{\text {th }}$ December 2010 from http://www.aseanfood.info/Articles/11016085.pdf.

Glendenning, J. C., Babu, S., \& Asenso-Okyere, K. (2010). Review of Agricultural Extension in India. Are Farmers' Information Needs Being Met? IFPRI Discussion Paper 01048. Retrieved January 27 from http://www.ifpri.org/sites/default/files/publications/ifpridp01048.pdf.

Gordijn, F. (2005). Learning across scale: A case study on learning and knowledge sharing to up-scale small-holder systems innovations in integrated watershed management in sub-Saharan Africa. M.Sc. Thesis. Retrieved on $15^{\text {th }}$ December 2010 from http://www.docstoc.com/docs/61545379/ 02Femke.

Government of Kenya (2010). Agricultural sector development strategy 2010-2020. 
Stephen WAMBUGU MAINA, John GOWLAND-MWANGI, Dave BOSELIE, Davies ONDURU, Betty CHELANG'AT BUSES. Up-Scaling Farmer Field Schools and Rainforest Alliance Certification among Smallholder Tea Producers in Kenya: Options, Opportunities and Emerging Lessons

Hartl, M. (2009). Technical and vocational education and training (TVET) and skills development for poverty reduction - do rural women benefit? Paper presented at the FAO-IFAD-ILO Workshop on Gaps, trends and current research in gender dimensions of agricultural and rural employment: differentiated pathways out of poverty Rome, 31 March - 2 April 2009. International Fund for Agricultural Development, Italy. Retrieved January 27 from http://idosi.org/wjas/wjas6(4)/3.pdf.

Hiller, S., Onduru, D. D., \& Jager, A. (2009). Sustainable tea production. An assessment of farmer field school in Kenya. Retrieved on $8^{\text {th }}$ January 2011 from http://edepot.wur.nl/5554.

Hirt, M. (2011). What does "Rainforest Alliance Certification" mean? Mother Earth News. Ogden Publications, Inc., 1503 SW 42nd St., Topeka, Kansas 66609-1265.

Kilimo Trust. (2010). Deepening and scaling-up the MATF initiative: Round 5 grants. Nairobi, Kenya: Ministry of Agriculture.

Kothari, C. R. (2008). Research methodology: Methods and techniques, (pp. 1-56). New Delhi: New Age International (P) Limited, Publishers (ISBN 10:81-224-1522-9).

Mosby's Dental Dictionary, 2nd edition. (2008). Cross-sectional study. http://en.wikipedia.org/wiki/ Cross-sectional_study.

Mugambi, K. (2010, Jan 26). Tea export earnings defy drought to hit Sh69 Billion. Retrieved on $13^{\text {th }}$ December 2010 from http://allafrica.com/stories/201001261008.html.

Mutai, P. (2011). Kericho County: The evergreen county that produces high quality tea. The Standard on Sunday, Sunday $9^{\text {th }}$ January 2011. Mombasa Road, Nairobi: The Standard Ltd.

Mwangi, J. G., Oloo, J. O., \& Maina, S. W. (2010). The effectiveness of farmer field schools' extension methodology in soil and water conservation using contour ploughing, unploughed strips, and farm yard manure. Problems of Education in the $21^{\text {st }}$ Century, 26 (26), 52-65.

Nyambati, E. M., Lusweti, C. M., Muyekho, F. N., \& Mureithi J. G. (2011). Up-scaling napier grass (Pennisetum purpureum schum) production using 'tumbukiza' method in smallholder farming systems in Northwestern Kenya. Journal of Agricultural Extension and Rural Development, 3 (1), 1-7.

Obulutsa, G. (2010). Kenya tea output rises, tourism earnings up. Retrieved on $13^{\text {th }}$ December 2010 from http://www.theafricareport.com/last-business-news/3296101-Kenyateaoutputrises, tourismearnin gsup.html.

Odhiambo, A. (2010). Kenya tea export grows by 50\%. Business Daily Sunday December 12, 2010. Retrieved on $13^{\text {th }}$ December 2010 from http://www.businessdailyafrica.com/CompanyIndustry/ Kenyateaexportgrowsby50percentindex.html.

Ombok, E. (2010). Kenya Tea Development Agency Plans to Build 10 Mini-Hydropower Projects. Retrieved on $13^{\text {th }}$ December 32010 from http://www.bloomberg.com/news/2010-09-24/kenyatea-development-agency-plans-to-build-10-mini-hydropower-projects.html

Rainforest (Alliance, 2011). Certification Manual. Rainforest Alliance Certified.

Rainforest (Alliance, 2011). Tea implementation guide for smallholders in East Africa.

Rusike, J., Masendeke, D., Twomlow, S. J., \& Heinrich, G. M. (2004). Impact of Farmer Field Schools on adoption of soil water and nutrient management technologies in dry areas of Zimbabwe. Global Theme on Agro-Ecosystems, Report no. 14. PO Box 776, Bulawayo, Zimbabwe: ICRISAT. pp: 24.

Stigter, K. (2010). A plea for climate field schools in China. INSAM, International Society for Agricultural Meteorology.

Sustainable Agriculture and Rural Development (SARD). (2007). SARD and scaling-up of good practices. Policy brief. ftp://ftp.fao.org/SD/SDA/SDAR/sard/SARD-upscaling\%20good\%20practices\%20$\%$ 20english.pdf.

Sustainable Agriculture Network SAN Group (2011). Group Certification Standard March 2011 (version 2). San José, Costa Rica. 
PROBLEMS

OF EDUCATION

IN THE $21^{\text {st }}$ CENTURY

Volume 43, 2012

158 Swanson, B. E., \& Rajalahti, R. (2010). Strengthening Agricultural Extension and Advisory Systems: Procedures for Assessing, Transforming, and Evaluating Extension Systems. Agriculture and Rural Development Discussion Paper 44. The International Bank for Reconstruction and Development/ The World Bank. Retrieved Feb 16 from http://www.g-fras.org/fileadmin/UserFiles/Documents/ Frames-and-guidelines/M_E/Strengthening-Agricultural-Extension-and-AS.pdf.

Swanson, B. (2008). Global review of good agricultural extension and advisory service practices. Rome: Food and Agriculture Organization of the United Nations.

The Standards (2011 Tuesday, February 8). KTDA adopts new power project to lower costs. Standard Group Centre. Nairobi. Kenya.

Van Tilburg, A., Kambewa, E., de Jager, A., \& Onduru, D. (2009). Up-scaling of smallholder participation in Global Value Chains. Chapter in the book on: "Value chain governance and endogenous growth: How can NGOs, firms and governments achieve inclusion and poverty reduction?"

Volkmann, J. (2008). Assessment of Certification Options for Wild Forest Coffee in Ethiopia, CoCE Project Report.

World Economic Forum (2011). The Consumption Dilemma. Leverage Points for Accelerating Sustainable Growth. Report prepared in collaboration with Deloitte Touche Tohmatsu and the World Economic Forum. 91-93 route de la Capite CH-1223 Cologny/Geneva Switzerland. Retrieved February 16 from http://www3.weforum.org/docs/WEF_ConsumptionDilemma_SustainableGrowth_Report_ 2011.pdf.

Yadal, M., Kotwal, P. C., \& Menaria B. L. (2007). Forest certification. A tool for sustainable forest management. Indian Institute of Forest Management. Bhopal. India.

Advised by Laima Railiene, University of Siauliai, Lithuania

Received: May 06, 2012

Accepted: May 23, 2012

\begin{tabular}{|ll|} 
Stephen Wambugu Maina & MSc in Agricultural Extension, Principal Agricultural Officer, Ministry \\
& of Agriculture - Narok South district, P. O. Box 15428-20100 Nakuru, \\
& Kenya. \\
& E-mail: Stephen67maina@yahoo.com \\
\hline John Gowland-Mwangi & Deputy Vice Chancellor (Research \& Extension), Egerton University, \\
& PhD in Agricultural Education and Extension, Professor of Agricultural \\
& Education and Extension, Egerton University, P. O. Box 536-20115 \\
& Egerton, Kenya. Cellphone +254-(0)723-466733; (0)732 241 089; \\
& (0)722-958069 \\
& E-mail: mwangijg5@yahoo.com; mwangijg@gmail.com \\
\hline Dave Boselie & Director Learning and Innovation, IDH, The Sustainability Initiative \\
Utrecht, the Netherlands. \\
E-mail: Boselie@idhsustainabletrade.com
\end{tabular}

